\title{
A STUDY ON THE PERFORMANCE OF FLY ASH AND SAND MIXES AS SUB-GRADE AND FILL MATERIAL
}

\author{
Satyanarayana.P.V.V ${ }^{1}$, Rahul.Ch ${ }^{2}$, Uday Kiran.Ch ${ }^{3}$, Raghava Rao E.V \\ ${ }^{1}$ Professor, Department of Civil Engineering, Andhra University, Visakhapatnam, India \\ ${ }^{2} P G$ Student, Department of Civil Engineering, Andhra University, Visakhapatnam, India \\ ${ }^{3} P G$ Student, Department of Civil Engineering, Andhra University, Visakhapatnam, India \\ ${ }^{4}$ Ph.D Scholar, Department of Civil Engineering, Andhra University, Visakhapatnam, India
}

\begin{abstract}
An excellent road network is an asset to any developing country particularly India and a perfect road network would complement its development. In pavements the most commonly used materials are sand, murrum, natural soils, etc., for sub-grade and fill material which proves to be a costly affair in terms of construction as well as maintenance. To maintain the quality and economy in construction, materials obtained from industrial wastes like pond ash, fly ash and bottom ash can be used. For this study a combination of fly ash and sand mixed at various proportions have been studied for geotechnical characteristics like compaction, strength characteristics like angle of shearing resistance, CBR etc. The results obtained from the tests show that these mixes attained high dry densities with high CBR and shear strength values. From the experimental data, it is also seen that a dosage of $40-50 \%$ of sand to the fly ash generates CBR values greater than $10 \%$ and angle of shearing resistance greater than $36^{\circ}$ can be used as sub-grade and fill materials in geotechnical applications.
\end{abstract}

Keywords: Fly ash, Sand, CBR, Sub-grade.

\section{INTRODUCTION}

Power sector is the backbone for industrial development of any country and India is one such and its economic development depends majorly on power sector. Thermal power plants using coal as fuel for power generation and produce more than $150 \mathrm{MT}$ of fly ash annually. Fly ash requires huge quantities of land for its disposal, in addition to environmental pollution. Inherent qualities like nonplastic and pozzolanic character with addition of admixtures such as lime, cement, etc. demands its usage in civil engineering applications like roads, embankments and low lying areas has been gaining importance.

Several researchers have done work on bulk utilization of fly ash in various civil engineering applications especially in geotechnical engineering as a construction and foundation material are Boominathan et.al $(1996,1999)^{1,2}$, Sridharan.A et.al (1997, 1998) ${ }^{11,12}$, Krishna Rao C.V et.al(2004) ${ }^{4}$, Satyanarayana.P.V.V et.al(2013) ${ }^{4,8,9,10}$, Ramakrishna et.al $(2001)^{8}$, Prabhakar et.al $(2003)^{7}$, Pandian, N.S et.al $(2002)^{5}$, Phanikumar, B.R et.al $(2007)^{6}$ Cokca, E.et.al $(2001)^{3}$ etc.

In the present study fly ash has been mixed with sand and tested for geotechnical properties such as compaction, strength, seepage and these mixes have been verified for suitability as sub-grade, embankment and fill material. For the bulk utilization of fly ash as a construction reduces the impact of harnessing natural material like gravels, sand, stones, soils etc. and the cost of construction thereby improving life of the structure.

\section{Materials and their Characterization}

\subsection{Fly ash}

Fly ash was collected from NTPC Paravada in Visakhapatnam,Andhra Pradesh and laboratory study was carried out for salient geotechnical characteristics of such as gradation, Atterberg limits, compaction and strength. The properties of Fly ash are shown in table 1 to 2 and fig 1 and 2.

Table 1: Geotechnical properties of Fly ash

\begin{tabular}{|c|c|}
\hline Property & Values \\
\hline Gravel (\%) & 0 \\
\hline Sand (\%) & 99 \\
\hline Fines (\%) & 01 \\
\hline a. Silt(\%) & 01 \\
\hline b. Clay(\%) & 0 \\
\hline Liquid Limit (\%) & NP \\
\hline Plastic Limit (\%) & NP \\
\hline I.S Classification & SP \\
\hline Specific gravity & 2.66 \\
\hline OMC (\%) & 6.0 \\
\hline MDD (g/cc) & 1.82 \\
\hline$\Phi($ degree) & 35 \\
\hline CBR (\%) & 6.0 \\
\hline
\end{tabular}




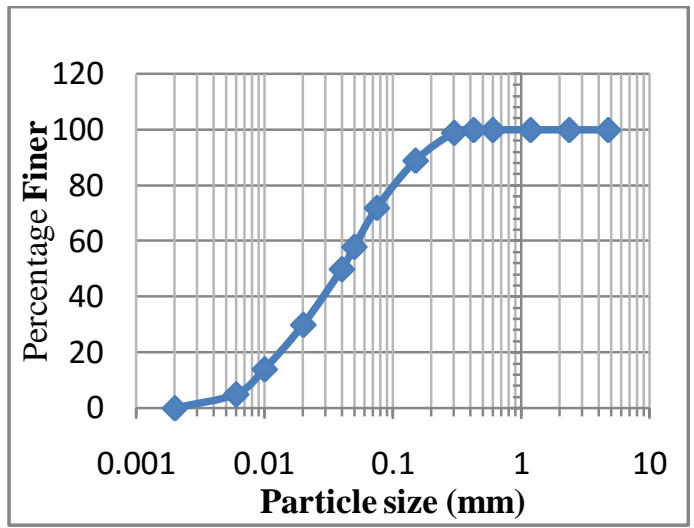

Fig 1: Gradation curve of fly ash

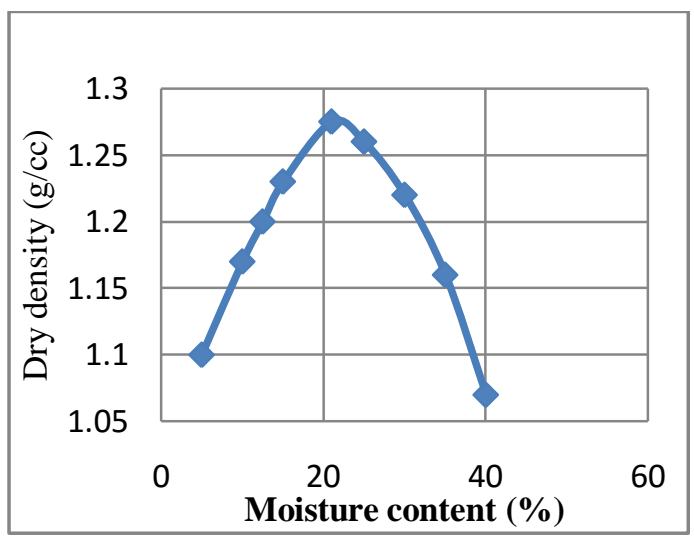

Fig 2: Compaction curve of Fly ash

From the characteristics of Fly ash it is observed that, majority of Fly ash particles passes through $425 \mu \mathrm{m}$ size consisting of fine sand and silt size particles and has nonplastic characteristics. It can also seen that Fly ash attains lower dry densities with wide variation in moisture contents.

\subsection{Sand}

Sand was collected from River Nagavali, Srikakulam in Andhra Pradesh. The collected Sand was dried and subjected for various geo-technical characterizations such as gradation, compaction, strength, etc., and the results are shown in table 2 and figure 3 and 4.

Table 2: Geotechnical properties of Sand

\begin{tabular}{|c|c|}
\hline Property & Values \\
\hline Gravel (\%) & 0 \\
\hline Sand (\%) & 28 \\
\hline Fines (\%) & 72 \\
\hline a. Silt(\%) & 72 \\
\hline b. Clay(\%) & 0 \\
\hline Liquid Limit (\%) & 28 \\
\hline Plastic Limit (\%) & NP \\
\hline I.S Classification & MLN \\
\hline Specific gravity & 2.1 \\
\hline OMC (\%) & 21.0 \\
\hline MDD (g/cc) & 1.28 \\
\hline$\phi(d e g)$ & 33 \\
\hline CBR(\%) & 4.0 \\
\hline
\end{tabular}

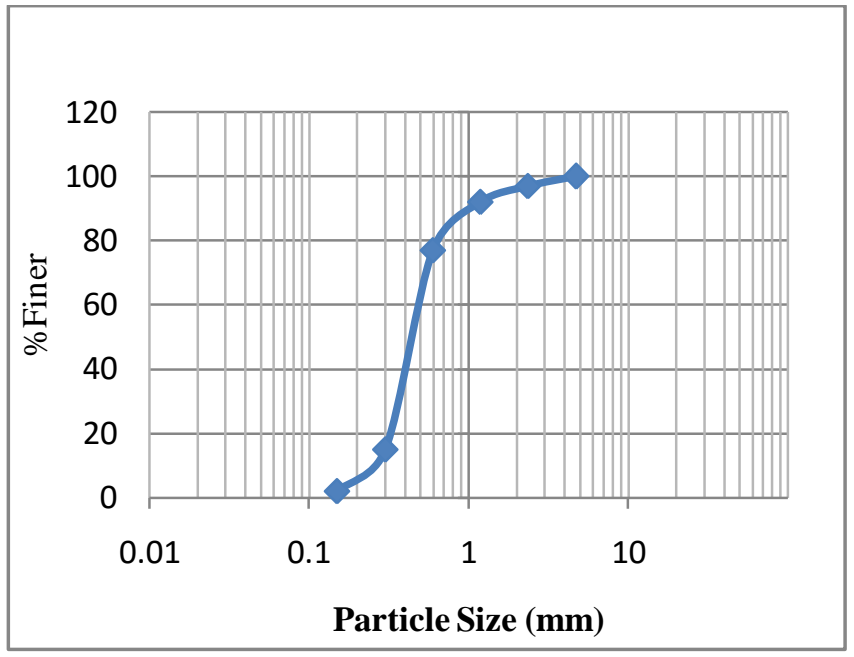

Fig 3: Gradation curve of Sand

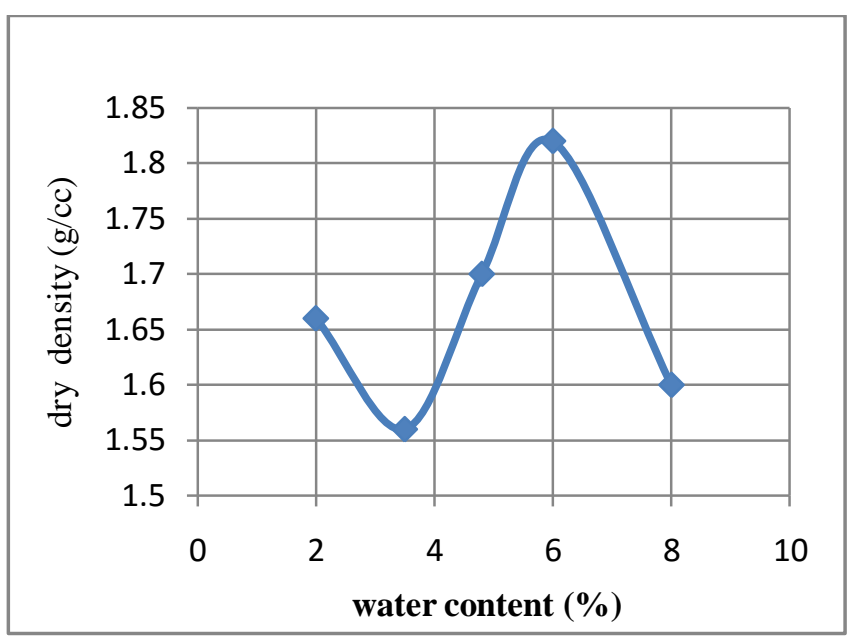

Fig 4: Compaction curve of Sand

\section{RESULTS AND DISCUSSIONS}

\section{Mixes of Fly ash and sand}

To know the performance of Fly ash with Sand as a geotechnical material, various percentages of sand such as $10,20, \ldots . . .100 \%$ have been added to Fly ash, and the mixes are designated as M1,M2......M11 and tested for geotechnical properties like compaction, strength and seepage.

\subsection{Compaction characteristics}

Mixes of fly ash and sand such as M1,M2......M11 have been subjected to heavy compaction by compacting the samples with a rammer of $4.89 \mathrm{~kg}$ for five layers and each layer subjected to 25 blows and their optimum moisture contents and maximum dry densities are determined as per IS 2720 part-8(1983). The results are shown in table 3 and fig 5 and 6. 
Table 3: Variation of OMC and MDD

\begin{tabular}{|c|c|c|c|}
\hline MIXES & $\begin{array}{c}\text { FLY ASH } \\
(\%)+ \\
\text { SAND }(\%)\end{array}$ & OMC (\%) & $\begin{array}{c}\text { MDD } \\
(\mathrm{g} / \mathrm{cc})\end{array}$ \\
\hline $\mathrm{M}_{1}$ & $100+0$ & 21 & 1.28 \\
\hline $\mathrm{M}_{2}$ & $90+10$ & 19.8 & 1.32 \\
\hline $\mathrm{M}_{3}$ & $80+20$ & 18.5 & 1.37 \\
\hline $\mathrm{M}_{4}$ & $70+30$ & 16 & 1.43 \\
\hline $\mathrm{M}_{5}$ & $60+40$ & 14 & 1.48 \\
\hline $\mathrm{M}_{6}$ & $50+50$ & 12.2 & 1.54 \\
\hline $\mathrm{M}_{7}$ & $40+60$ & 11.5 & 1.60 \\
\hline $\mathrm{M}_{8}$ & $30+70$ & 10.8 & 1.68 \\
\hline $\mathrm{M}_{9}$ & $20+80$ & 8.2 & 1.74 \\
\hline $\mathrm{M}_{10}$ & $10+90$ & 7 & 1.78 \\
\hline $\mathrm{M}_{11}$ & $0+100$ & 6 & 1.82 \\
\hline
\end{tabular}

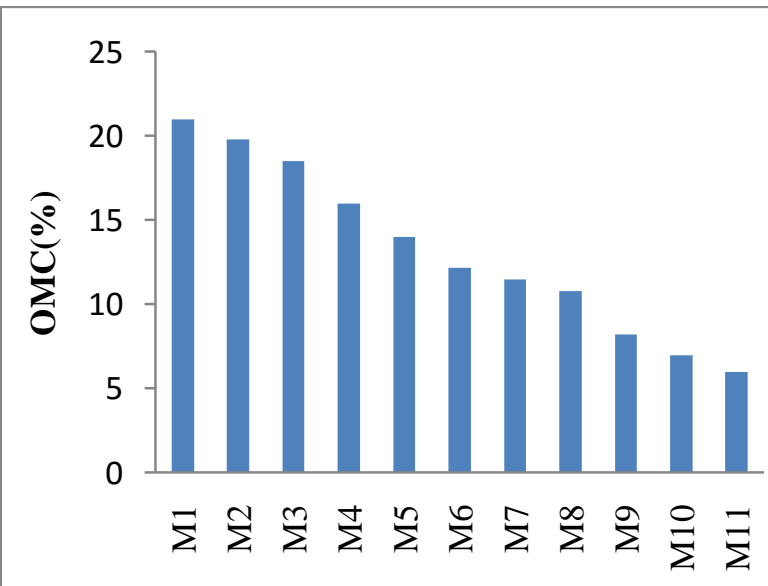

Flyash+Sand mixes

Fig 5: Variation of OMC

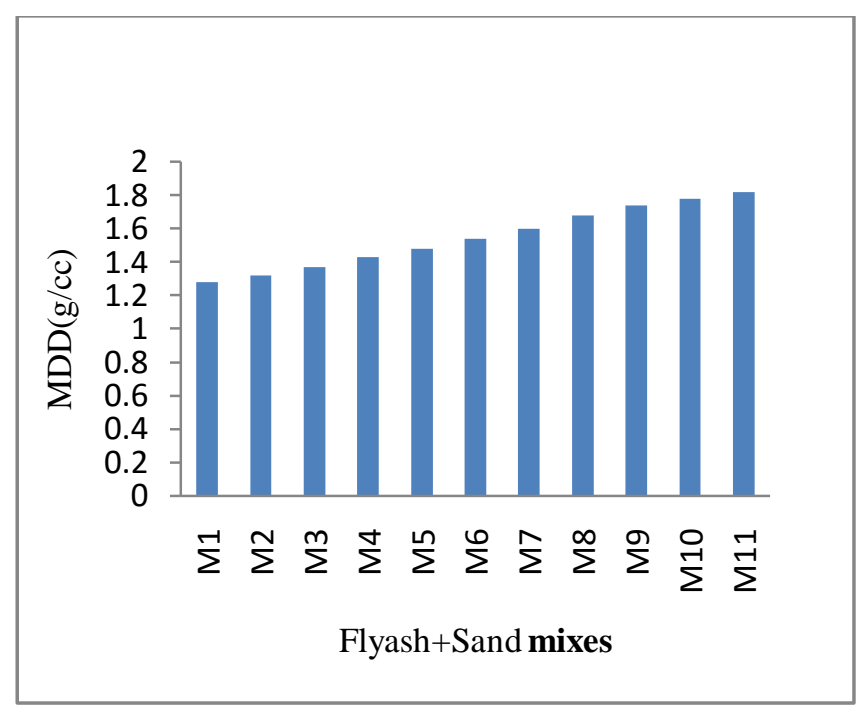

Fig 6 : Variation of MDD
From the experimental data it is observed that as a percentage of sand is increasing, the optimum moisture content values are decreasing and maximum dry density values are increasing. A steady decrease in optimum moisture content values were observed up to $20 \%$, and a rapid decrease was observed from 20 to $50 \%$ followed by a steady decrease was observed up to $90 \%$ dosage of sand. Similarly a steady increase in maximum dry densities were observed up to $20 \%$ and a rapid increase was observed up to $50 \%$ followed by a steady increase up to $90 \%$ dosage of sand. The decrease in optimum moisture contents are due to availability of the percentage of sand particles in fly ashsand mixes which require less water to coat. Increase in maximum dry densities are due to effective replacement of formed voids by sand and Fly ash particles make the mixes dense.

\subsection{Angle of shearing resistance $(\phi)$}

To obtain the shear strength values of Fly ash and sand mixes, the samples were compacted at their maximum dry densities (MDD) under heavy compaction and direct shear test was performed as per IS 2720 part-. The results are shown in table 4 and fig 7.

Table 4: Variation of angle of shearing resistance

\begin{tabular}{|c|c|c|}
\hline MIXES & $\begin{array}{c}\text { FLY } \\
\text { ASH(\%)+SAND(\%) }\end{array}$ & $\boldsymbol{\phi ( d e g )}$ \\
\hline $\mathrm{M}_{1}$ & $100+0$ & 33 \\
\hline $\mathrm{M}_{2}$ & $90+10$ & 34 \\
\hline $\mathrm{M}_{3}$ & $80+20$ & 35 \\
\hline $\mathrm{M}_{4}$ & $70+30$ & 36 \\
\hline $\mathrm{M}_{5}$ & $60+40$ & 38 \\
\hline $\mathrm{M}_{6}$ & $50+50$ & 38 \\
\hline $\mathrm{M}_{7}$ & $40+60$ & 37 \\
\hline $\mathrm{M}_{8}$ & $30+70$ & 36 \\
\hline $\mathrm{M}_{9}$ & $20+80$ & 35.5 \\
\hline $\mathrm{M}_{10}$ & $10+90$ & 35 \\
\hline $\mathrm{M}_{11}$ & $0+100$ & 34 \\
\hline
\end{tabular}

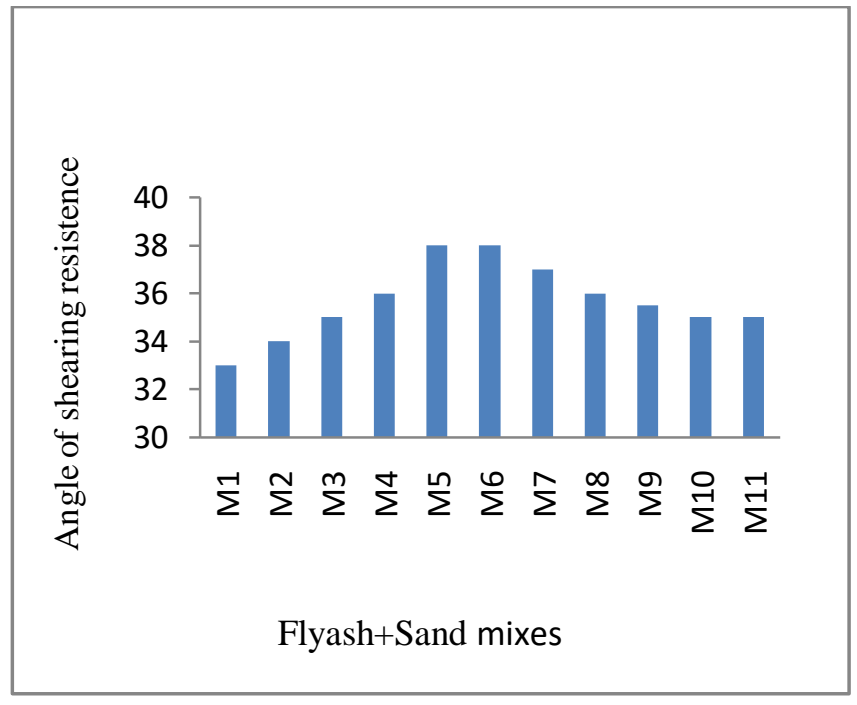

Fig 7: Variation of angle of shearing resistance 
From the experimental data it is observed that as the percentage of sand is increasing the angle of shearing resistance values are increasing up to $50 \%$ and decreasing . A steady increase was observed up to $30 \%$ and a rapid increase was observed in between $30 \%$ - $50 \%$ followed by steady decrease upto $80 \%$ dosages of sand. Maximum values attained in the range of $40 \%-50 \%$. Increase in angle of shearing resistance values are due to development of frictional resistance by filling up of formed voids by the lower sizes of Fly ash and sand particles. Hence a combination of Fly ash and sand particles mobilizes more frictional resistance than individual Fly ash and sand particles.

\subsection{Coefficient of Permeability}

Variable head permeability test and constant head permeability test were conducted for all the eleven samples, compacted at their maximum dry densities and tested as per (IS: 2720-part 17 -1986).

Table 5: Variation of Coefficient of Permeability (k)

\begin{tabular}{|c|c|c|}
\hline MIXES & $\begin{array}{c}\text { FLYASH(\%)+ } \\
\text { SAND(\%) }\end{array}$ & $\begin{array}{c}\text { Coefficient of } \\
\text { Permeability(k) } \\
\text { cm/sec }\end{array}$ \\
\hline $\mathrm{M}_{1}$ & $100+0$ & 0.00026 \\
\hline $\mathrm{M}_{2}$ & $90+10$ & 0.00054 \\
\hline $\mathrm{M}_{3}$ & $80+20$ & 0.00078 \\
\hline $\mathrm{M}_{4}$ & $70+30$ & 0.00096 \\
\hline $\mathrm{M}_{5}$ & $60+40$ & 0.0025 \\
\hline $\mathrm{M}_{6}$ & $50+50$ & 0.0048 \\
\hline $\mathrm{M}_{7}$ & $40+60$ & 0.0072 \\
\hline $\mathrm{M}_{8}$ & $30+70$ & 0.0092 \\
\hline $\mathrm{M}_{9}$ & $20+80$ & 0.018 \\
\hline $\mathrm{M}_{10}$ & $10+90$ & 0.042 \\
\hline $\mathrm{M}_{11}$ & $0+100$ & 0.063 \\
\hline
\end{tabular}

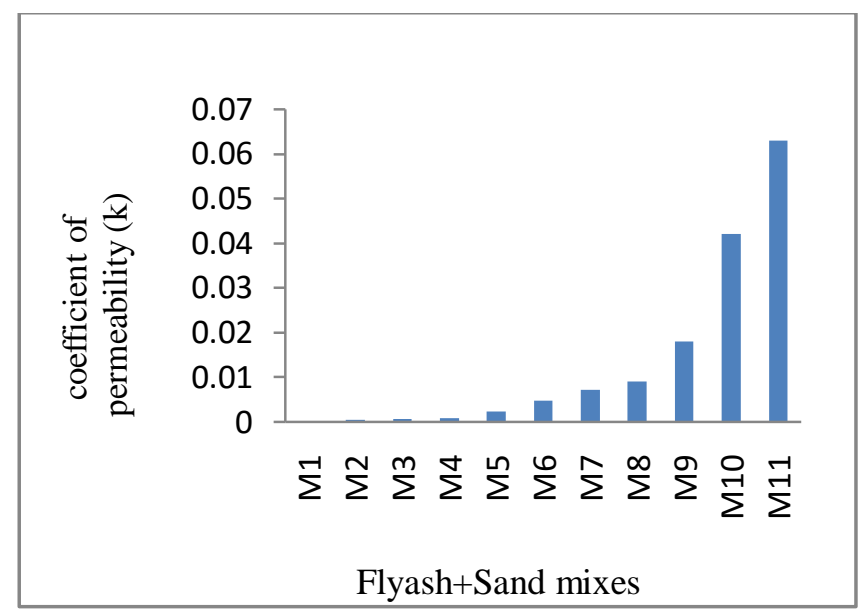

Fig 8: Variation of Coefficient of Permeability (k)

From the experimental data it is observed that as the percentage of sand is increasing the coefficient of permeability values are increasing. A steady increase was observed up to $30 \%$ and a rapid increase was observed in between $30 \%$ - $50 \%$ followed by a steady increase up to $100 \%$ dosage of sand. Increase in the coefficient of permeability values are due to occupation of more sand particles in place of Fly ash particles. Hence a combination of Fly ash and sand particles accepting pervious conditions to use as a well drainage material.

\subsection{California Bearing Ratio}

To know the CBR characteristics of Fly ash and sand mixes, the samples were compacted in the CBR mould at their maximum dry densities under heavy compaction energy and the samples were soaked in water for 4 days. After completion of the required soaking period, the samples were tested at the strain rate of $1.25 \mathrm{~mm} / \mathrm{min}$ as per IS 2720 part -. The results are shown in table 6 and fig 9 .

Table 6: Variation of CBR

\begin{tabular}{|c|c|c|}
\hline MIXES & $\begin{array}{c}\text { Fly ash (\%) } \\
+ \text { Sand (\%) }\end{array}$ & CBR \\
\hline $\mathrm{M}_{1}$ & $100+0$ & 4 \\
\hline $\mathrm{M}_{2}$ & $90+10$ & 6 \\
\hline $\mathrm{M}_{3}$ & $80+20$ & 9 \\
\hline $\mathrm{M}_{4}$ & $70+30$ & 12 \\
\hline $\mathrm{M}_{5}$ & $60+40$ & 16 \\
\hline $\mathrm{M}_{6}$ & $50+50$ & 15 \\
\hline $\mathrm{M}_{7}$ & $40+60$ & 13 \\
\hline $\mathrm{M}_{8}$ & $30+70$ & 12 \\
\hline $\mathrm{M}_{9}$ & $20+80$ & 10 \\
\hline $\mathrm{M}_{10}$ & $10+90$ & 9 \\
\hline $\mathrm{M}_{11}$ & $0+100$ & 8 \\
\hline
\end{tabular}

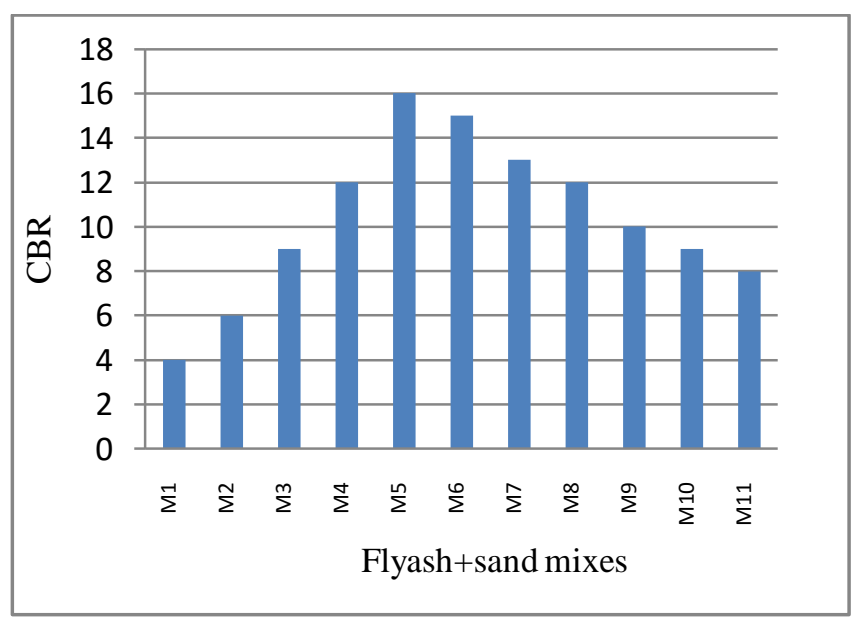

Fig 9: Variation of CBR

From the experimental data it is observed that as the percentage of sand is increasing CBR values are increasing. Maximum values are attained for $40-50 \%$ dosage of sand are in the range of 15-16. As the percentage of sand is 
increasing in the mixes, frictional resistance values are increasing by achieving of high CBR values against compression. Hence a dosage of $50 \%$ to $60 \%$ of sand can be effectively replaced by Fly ash as sub-grade material.

\section{APPLICATIONS}

1. Based on the grain size distribution fly ash has dominated by silt size particles whereas sand has dominated by medium to fine sand size particles. As the percentage of sand is increasing in the fly ash-sand mixes attained high strength values like angle of shearing resistance $(\phi)$ as $38^{\circ}$ and CBR as $15-16 \%$.

2. $50-60 \%$ sand can be considered as effective replacement in utilization of fly ash in fly ash-sand mixes by maintaining high strength values against shear and compression.

3. High values of CBR $>10 \%$ and high angle of shearing resistance values $\phi>36$ degrees at high moisture contents and high dry densities $>15-16 \mathrm{KN} / \mathrm{m}^{3}$. Hencefly ash-sand mixes can be effectively used as sub-grade, fill and embankment material.

\section{CONCLUSIONS}

Test results says that sand and fly ash are two coarse grained and non plastic materials can be chosen as construction material. Combination of Sand and fly ash coherently give high strength values in terms of Angle of shearing resistance $\left(38^{0}\right)$ and CBR $(16 \%)$ can be effectively used in civil constructions such as Embankment, Sub-grade, fill material, and Reinforced earth material.

\section{REFERENCES}

[1] Boominathan, A. and Hari, S. (1990), Behavior of Fly ash under Static and Cyclic Loading. Proc. of IGC-99, Calcutta, 324-326.

[2] Boominathan, A. and Kumar Raina J., (1996). Lime treated Fly ash as Embankment Material, Proc. of IGC96, Madras; 523-526.

[3] Cokca, E. (2001) Use of class C Fly ashes for the stabilization of an expansive soil, journal of geotechnical and Geo environmental Engineering, 127, 568-573.

[4] Krishna Rao C.V,Satyanarayana P.V.V,Rama Rao .R,(2004)"Utilisation of lime-fly ash stabilized expansive soils in Roads and Embankments".Indian Geo-technical Confirence(2004)Pp.465-467.

[5] Pandian, N.S. and Krishna, K.C. (2002), California bearing ratio behavior of cement stabilized Fly ash-soil mixes, Journal of testing and evaluation, 30(6), 1-5.

[6] Phanikumar, B.R. and Sharma, R.S. (2007), Volume changes Behavior of Fly ash-stabilized clays, Journal of materials in Civil Engineering, 19(1), 67-64.

[7] Prabakar, J., Dendorkar, n., and Morchhale, R.K (2003), Influence of Fly ash on strength behavior of typical soils. Construction and building material, pp. 263-267.

[8] RamaRao.R,Satyanarayana P.V.V, CVKRAO," Fly ash - a construction material in rural roads", $4^{\text {th }}$ International
Conference on Ground Improvement Techniques 2 (1), 645-648.

[9] Ramakrishnan, A.K., Natarajan, K., and Ravichandran, K. (2001), Stabilization of Annamalainagar Clay with lime-Fly ash, Indian Geotechnical Conference, Dec. 1416, 2001, pp. 251-254.

[10] Satyanarayana.P.V.V Kiran B. Biradar, U.Arun Kumar, Influence of Steel Slag and Fly Ash on Strength Properties of Clayey Soil: A Comparative Study International Journal of Engineering Trends and Technology (IJETT) ) Volume 14 Issue 2 Pages $61-6$ ISSn No:2349-0918

[11] Satyanarayana P.V.V., K.Prasada rao, U.Arun kumar and K.Sivaramakrishna (2013), "Bulk utilization of fly ash lime sodium silicate mixes in geotechnical applications". Pollution Research Paper, August, Vol.32, Issue 02.

[12] Sridharan, A., Pandian, N.S. and Srinivas, S. (1998), Use of Fly ash to improve the CBR of soil, Indian Geotechnical Conference, Vol. 2, 261-264.

[13] Sridharan, A., Prashanth, J.P. and Sivapullaiah, P.V. (1997), Effect of Fly ash on the unconfined compressive strength of black cotton soil, Ground Improvement, Vol. $1,169-175$.

\section{BIOGRAPHIES}

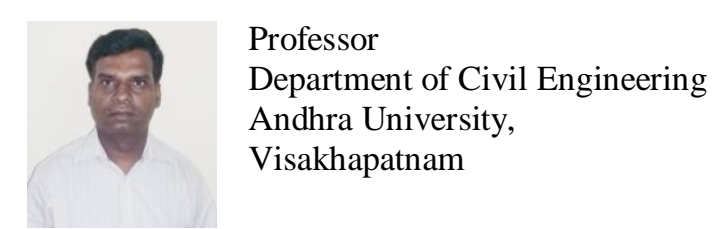

